Review

\title{
Gastro-Esophageal Reflux in the Newborn: Pathologic Event or Does Spit Happen?
}

Gretchen Stepanovich, Steven M. Donn*

The Division of Neonatal-Perinatal Medicine, Department of Pediatrics, Michigan Medicine, University of Michigan, Ann Arbor, MI, USA; E-Mails: sgretche@med.umich.edu; smdonnmd@med.umich.edu

* Correspondence: Steven M. Donn; E-Mail: smdonnmd@med.umich.edu

Academic Editor: Xia Jiang

Special Issue: Gastroesophageal Reflux Disease: From Heartburn to Esophageal Adenocarcinoma

OBM Hepatology and Gastroenterology Received: April 19, 2021

2021, volume 5, issue 3

Accepted: August 10, 2021

doi:10.21926/obm.hg.2103060

Published: August 13, 2021

\begin{abstract}
Infants admitted to Neonatal Intensive Care Units (NICUs) are among the most vulnerable patients in medicine and are at risk for a variety of morbidities, many of which require pharmacologic therapy. Gastroesophageal Reflux Disease (GERD) is a common diagnosis in the NICU patient population and may or may not represent a truly pathologic process. Regardless, pharmacologic therapy is provided to many infants, who are already exposed to an inordinate number of pharmacologic agents, of which most are off label and have an inadequate evidence base to establish either efficacy or safety. Furthermore, as infancy represents a time of dramatic growth and development, many conditions resolve over time, making treatment unnecessary and potentially dangerous. Infants with GERD, especially those born prematurely, exemplify the complexity of attempting pharmacologic therapy with unproven consistent benefit versus "watching and waiting." The following will present physiology of GERD, gastrointestinal tract anatomy and development as well as options for pharmacologic and non-pharmacologic therapies.
\end{abstract}

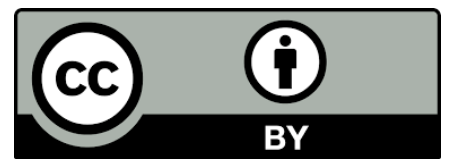

(C) 2021 by the author. This is an open access article distributed under the conditions of the Creative Commons by Attribution License, which permits unrestricted use, distribution, and reproduction in any medium or format, provided the original work is correctly cited. 


\section{Keywords}

Gastroesophageal reflux; gastroesophageal reflux disease (GERD); lower esophageal sphincter (LES); transient lower esophageal sphincter relaxation (TLESR); Histamine-2 receptor antagonist (H2RA); proton pump inhibitor (PPI); pharmacologic management

\section{Introduction}

Gastro-esophageal Reflux (GER) is defined as the retrograde passage of gastric contents into the esophagus $[1,2]$. In the neonatal population, it is considered to be a normal physiologic process, a consequence of transient lower esophageal sphincter relaxations (TLESRs), which may occur multiple times each hour [3-5]. Though a common and normal phenomenon, it is blamed for a plethora of problematic signs, especially in preterm infants, including apnea, upper airway irritation, aspiration and worsening of lung disease, irritability, feeding intolerance, and failure to thrive, with the adverse consequences of reflux deemed to comprise Gastroesophageal Reflux Disease (GERD) $[1,2,5-7]$. Given the frequency and apparent physiologic normality of reflux, can this truly be considered a disease, or, does "spit happen?"

GERD is one of the most commonly diagnosed conditions in the neonatal intensive care unit (NICU), especially in infants born prematurely or those with congenital anomalies of the gastrointestinal (GI) tract. In a retrospective cohort study performed over a three year period and involving nearly 19,000 premature infants in 33 NICUs, just over $10 \%$ of the infants were diagnosed with GERD; the length of stay was 30 days greater and the additional cost of the NICU stay was more than $\$ 70,000$ per patient [8]. Therefore, it stands to reason that clinicians would make attempts to treat GERD, and pharmacologic agents are often the first-line treatment for many conditions encountered in the NICU. In fact, a retrospective cohort study of 3,252 infants across 43 United States NICUs from 2007-2016 involving infants with severe bronchopulmonary dysplasia, a common pulmonary diagnosis in premature infants that may be related to GERD, studied just this. These infants were exposed to an average of 30 different medications during their NICU stay [9]. Thus, these highly vulnerable patients are frequently subjected to an inordinate number of pharmacologic agents, often used in an off-label manner and without good evidence to support their safety or efficacy. In a study of 220 infants who received at least one medication during their NICU or nursery stay in Brazil over a one-year period, $96.4 \%$ of infants were exposed to off-label medications and $66.8 \%$ to unlicensed medications [10]. Complicating appropriate treatment for NICU patients is the fact that the natural history of many disorders is unknown; many conditions are physiologic and resolve over time without intervention, making treatment unnecessary and potentially dangerous. Babies with GERD, especially those who are premature, epitomize this conundrum. This paper will discuss upper GI tract development, the physiology and diagnosis of GERD, and the therapeutic options. Emphasis will be placed on concerns regarding pharmacologic treatment with options for non-pharmacologic management also presented.

Information for this review was gathered via searches using the PubMed and Ovid databases, with search terms including neonatal reflux, histamine-2 receptor antagonist (H2RA), proton pump inhibitor (PPI), transient lower esophageal relaxation (TLESR), lower esophageal sphincter (LES), and development of the esophagus and LES, with review of references cited in the relevant manuscripts. 


\section{Gastrointestinal Tract Development}

Gastrointestinal (GI) tract development begins between three and four weeks' gestation with generation of the esophagus and proximal GI tract from the primitive foregut $[11,12]$. Immature neurons from both the sympathetic and parasympathetic nervous systems are present in the esophagus by 8 weeks' gestation, and the cellular machinery needed for coordinated motility is present by 14 weeks' gestation. Once mature, these circuits will dictate esophageal motility [13]. Manometric investigations of premature infants have shown appropriate lower esophageal sphincter tone and normal peristaltic esophageal activity in response to swallowing to be present at least as early as 26 weeks' gestation, though not all activity is organized [3].

The esophagus (Figure 1) is comprised of four layers: mucosa, submucosa, muscularis propria, and adventitia. The innermost layer, the mucosa, consists of squamous epithelium, connective tissue, and smooth muscle. The submucosa contains connective tissue, blood vessels, lymphatics, and nerves in the form of Meissner's plexus, which has several functions but does not contribute to esophageal motility. The muscularis propria consists of two muscular layers; craniocaudally, it transitions from striated to smooth muscle and is comprised exclusively of smooth muscle in the distal two-thirds of the esophagus. Between the two muscular layers lies the myenteric plexus, whose input creates peristaltic activity within the GI tract. The outermost layer is the adventitia, a fibrous layer that surrounds the esophagus and connects it to other structures, including the phrenoesophageal ligament, which helps anchor the esophagus to the diaphragm. The esophagus has two sphincters, an upper and lower esophageal sphincter, to help prevent retrograde flow into the airway and esophagus, respectively $[14,15]$.
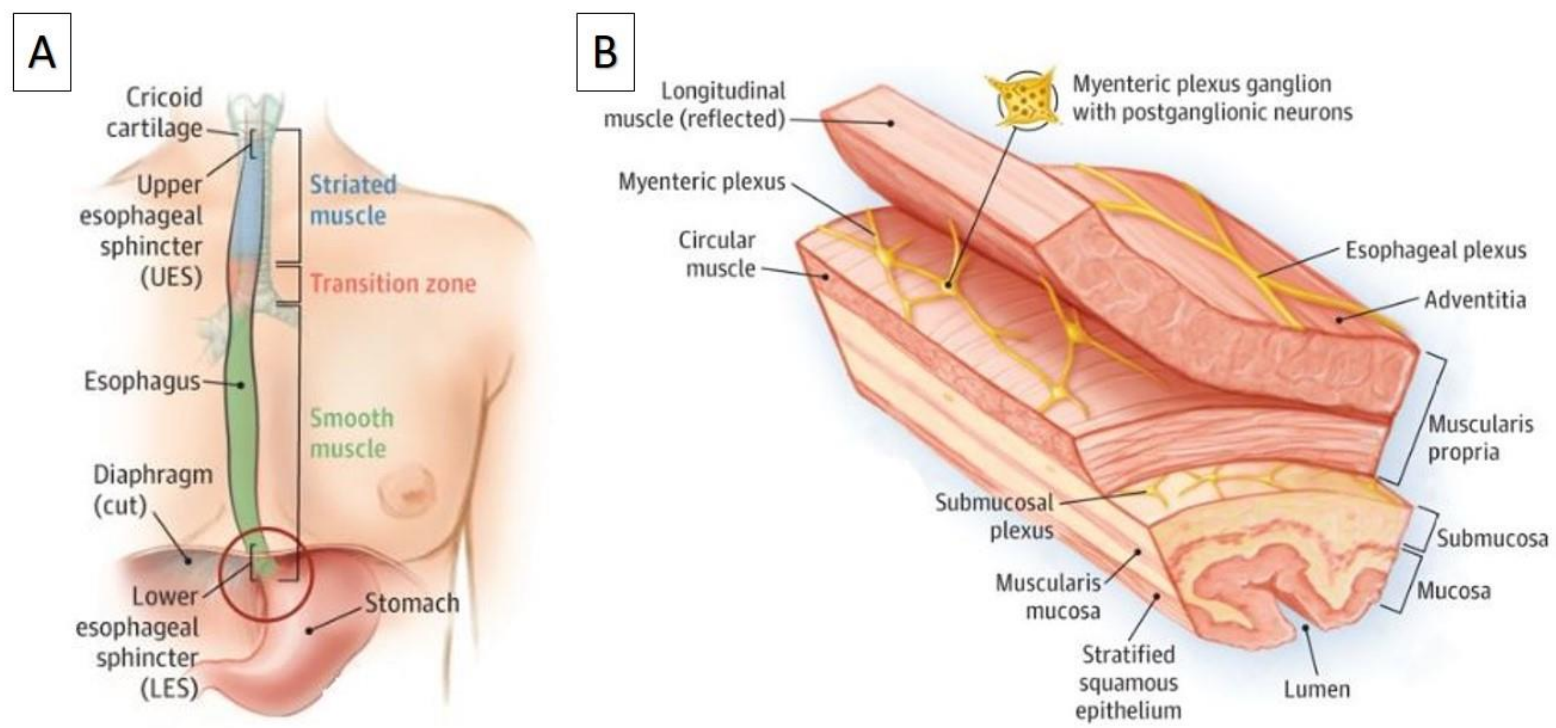

Figure 1 A) General anatomy of the upper gastrointestinal tract. B) Composition of the esophageal wall and its innervation. Modified and used with permission from Pandolfino, J. E. and A. J. Gawron (2015). "Achalasia: a systematic review." JAMA 313(18): 18411852. 
To keep gastric contents within the stomach, the Lower Esophageal Sphincter (LES) (Figure 2) must maintain a tonic pressure greater than that generated by gastric contractions as digestion begins and propels gastric contents through the Gl tract $[3,4]$. Both smooth and skeletal muscles contribute to the pressure generated by this two-layer sphincter. The internal mechanism is created by the intrinsic muscles of the distal esophagus and oblique fibers of the proximal stomach, and the external mechanism is generated by the crural diaphragm. These structures are innervated by the vagus and phrenic nerves, respectively, and their coordinated action facilitates simultaneous relaxation, allowing movement of esophageal contents into the stomach [3, 14-17].

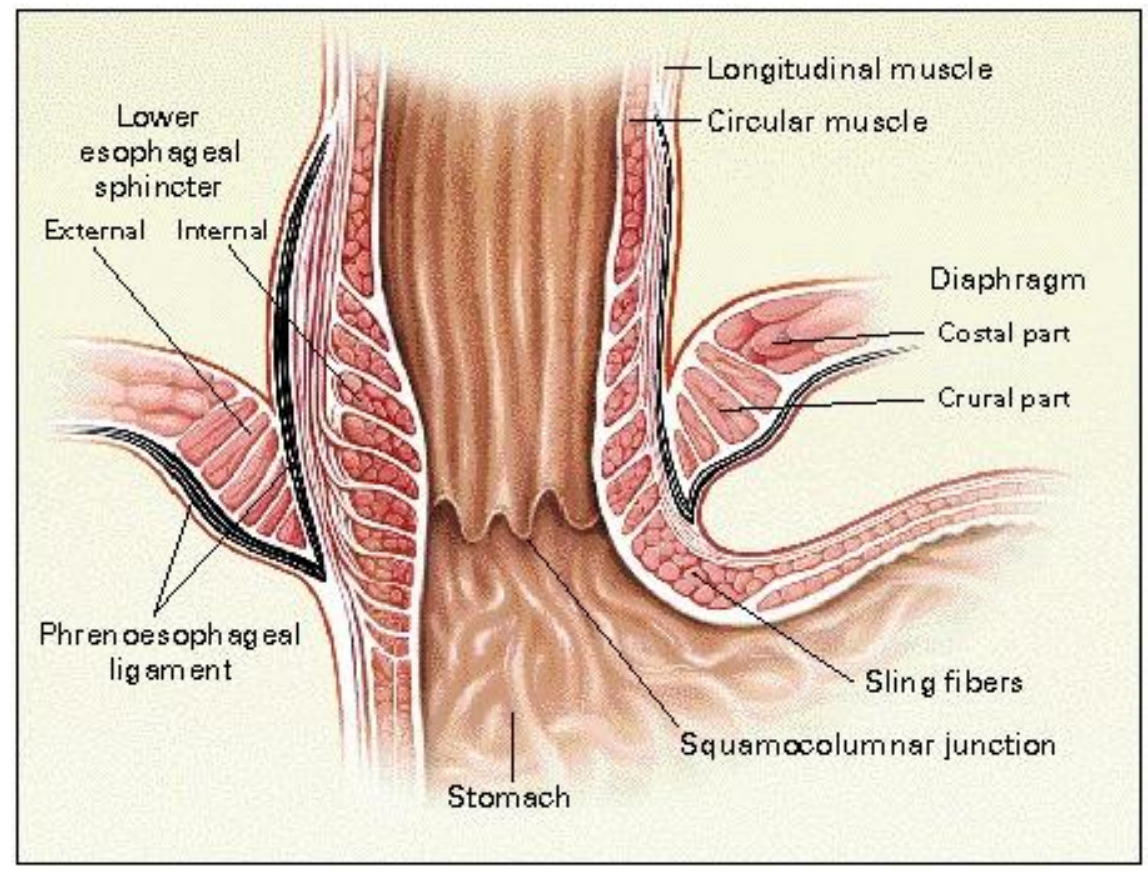

Figure 2 Anatomy of the Lower Esophageal Sphincter (LES). Used with permission from Mittal RK, Balaban DH. The esophagogastric junction. N Engl J Med. 1997 Mar 27;336(13):924-32.

Historically, it was thought that incompetence of the LES was the primary mechanism behind GERD, especially in the preterm infant. However, many recent studies have supported Transient Lower Esophageal Relaxations (TLESRs), a decrease in the tone of the LES unrelated to swallowing, to be the primary mechanism behind the occurrence of reflux $[1,3,5,17,18]$. The LES relaxation in TLESRs is typically of longer duration than those observed following meal propagation after swallowing, and therefore may allow a proportionately larger refluxed volume [5, 15-17]. While reflux in infants tends to be less acidic than adults, resulting presumably at least in part from the buffering capacity of milk [19], infants with reportedly symptomatic reflux tend to have more acidic refluxate than those with proven TLESRs without signs of GERD [16-18, 20].

\section{Diagnosing GERD}

The diagnosis of GERD can be challenging. While there is no "gold standard" test to diagnose GERD, there are multiple options to help support or refute the presence of pathologic reflux. An 
esophageal $\mathrm{pH}$ probe measures the $\mathrm{pH}$ within the esophagus. If left in situ for 12-24 hours, it can be used to quantify the fraction of time acidic contents are present in the esophagus, though ideally the $\mathrm{pH}$ should be correlated with clinical signs to support GERD. Esophageal Multichannel Intraluminal Impedance (MII) testing detects the presence of fluid in the esophagus; results may be particularly meaningful if used in combination with a pH probe [20]. An Upper GI Contrast Study can help define gastrointestinal anatomy, reveal a potential obstruction or stricture that may predispose an infant to reflux, and could show refluxed contrast on early fluoroscopic images. However, it cannot assess the frequency of reflux events. A nuclear medicine scintigraphic study ("milk scan"), in which a radionuclide tracer is added to an infant's milk, can reveal whether the milk is refluxed and/or aspirated $[1,5,19]$.

In a study published in 2003 in which GERD was diagnosed using a pH probe, investigators found clinical assessment by care providers to be a very effective way to suspect reflux, with a positive predictive value of $73 \%$ and negative predictive value of $85 \%$ [17]. This may provide support for a way in which reflux may be diagnosed: a trial of therapy in infants in whom providers have a strong suspicion for GERD, with a presumptive confirmation if the suspected GERD-related signs improve following the prescribed intervention.

\section{Gastroesophageal Reflux Disease (GERD)}

Signs associated with GERD in infants have included apnea, airway irritation, worsening of lung disease, poor growth, and apparent pain or irritability $[1,2,6,7,19,21]$. Despite this, the evidence to support reflux as a cause of these findings is slim, and agreement is poor among subspecialists who care for infants regarding which signs are attributable to GE reflux, as well as whether or how it should be treated [22]. Many studies support or refute adverse sequelae of GER, but results have been mixed. Several published studies have shown a positive correlation between reflux and apnea, especially in preterm infants, while others have shown no such link [6, 23, 24]. Furthermore, studies have demonstrated both the presence and absence of an association between chronic lung disease and reflux [25], although the positive associations were not necessarily causative. Pediatric otolaryngology literature reports the potential development of subglottic stenosis, laryngitis, chronic cough, obstructive apnea, and bronchospasm from pathologic GERD secondary to airway irritation from gastric acid, pepsin, bile acids, and pancreatic enzymes in the refluxate [7]. Regardless of whether reflux was a cause or consequence of associated morbidities, multiple studies have shown an increased cost and duration of hospitalization of infants with GERD [8, 26, 27], which begs the question: shouldn't GERD just be treated?

\section{GERD Treatments}

Given the myriad of findings often attributed to reflux, treatments to reduce the frequency, volume or acidity of reflux events, or to ameliorate the signs, would be ideal. Both pharmacologic and non-pharmacologic interventions have been trialed. 


\subsection{Pharmacologic Agents}

5.1.1 Acid-Blocking Agents: Histamine 2 Receptor Antagonists (H2RAs) and Proton Pump Inhibitors (PPIs) (Figure 3)

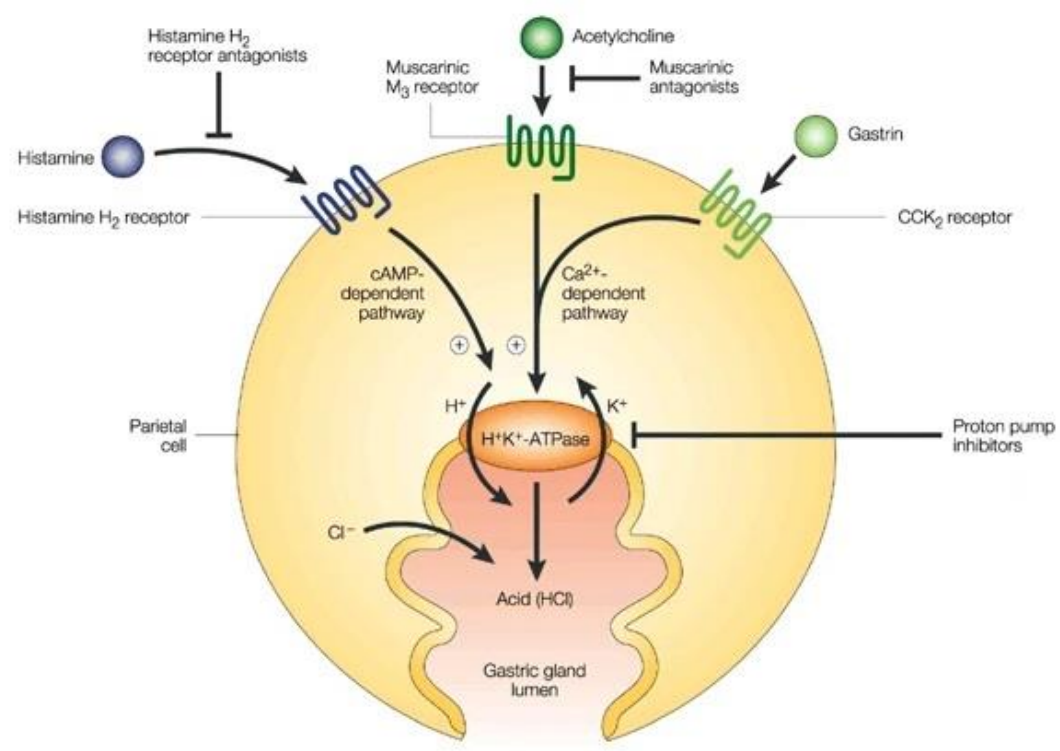

Figure 3 Mechanism of action of Histamine Receptor Antagonists (H2RAs) and Proton Pump Inhibitors (PPIs). Also note metoclopramide action at the muscarinic M3 receptor. Modified and used with permission from: Olbe L, Carlsson E, Lindberg P. A proton-pump inhibitor expedition: the case histories of omeprazole and esomeprazole. Nat Rev Drug Discov. 2003 Feb; 2(2): 132-9.

Gastric parietal cells are epithelial cells that line the fundus and cardiac regions of the stomach and secret hydrochloric acid. Histamine 2 Receptor Antagonists (H2RAs) are competitive inhibitors of histamine at the $\mathrm{H} 2$-receptors of the gastric parietal cells. This results in downstream inhibition of gastric acid secretion [28]. Their use, however, has not resulted in either fewer TLESRs or a decreased volume of refluxate. However, refluxed contents are less acidic and, therefore, should result in decreased irritation to esophageal and airway mucosa, theoretically mitigating many of the consequences of reflux [29]. Examples of H2RAs used in the NICU include ranitidine and famotidine (each has both enteral and IV preparations) [28].

Whereas H2RAs block parietal cell histamine receptors and reduce acid suppression by preventing the histamine-stimulated signaling that leads to acid generation, Proton Pump Inhibitors (PPIs) suppress gastric acid secretion by directly and irreversibly inhibiting the parietal cell $\mathrm{H}+/ \mathrm{K}+$ ATP pump [29]. Common PPIs include omeprazole, lansoprazole and esomeprazole. Each has enteral and IV preparations [30, 31].

Despite the theoretical justification, evidence to support the benefit of these agents in the neonatal population is lacking. While one RCT involving omeprazole use over a seven-day period in 10 preterm infants (34-40 weeks' corrected gestational age) revealed improved physiologic measures of reflux (reduced acid reflux events as measured by 24-hour pH probe), it did not reduce the number of clinical reflux episodes reported by the infants' care providers [32]. Furthermore, neither H2RAs nor PPIs are FDA-approved for treatment of reflux in children less than one year of 
age. This may be at least in part a result of the many studies that have reported significant safety concerns related to the administration of these agents to neonates, including an increased risk of infection, skeletal fractures, allergic disease, cardiac arrhythmias, necrotizing enterocolitis (NEC), intraventricular hemorrhage (IVH), and even death [33-40].

Infection. Gastric acidity is part of the innate immune system, creating a first line of defense within the $\mathrm{Gl}$ tract by generating a $\mathrm{pH}$ that is toxic to potential microbial invaders who could otherwise traverse the gastrointestinal mucosa to gain access to the bloodstream. In neonates, gastric acidity increases from birth through the first 10 days of life, establishing a primitive, early defense barrier to organisms gaining access to the Gl tract [41]. Therefore, it follows that suppression of this mechanism of defense could result in an increased risk of infection, especially to premature infants, who already have a less robust immune system and a heightened vulnerability to infection. A multicenter randomized controlled trial published in 2006 investigating the effectiveness and safety of lansoprazole in 162 infants revealed no benefit compared to placebo and an increase in lower respiratory tract infections in treated infants, though the difference was not statistically significant [34]. This was followed by a 2009 study in adults that showed an increased risk of hospital-acquired pneumonia in patients who received acid-suppressive medications during their inpatient stay [42]. In a secondary analysis of a study investigating the benefit of lactoferrin to reduce the risk of late-onset sepsis, the use of PPIs or H2RAs was found to be significantly associated with the incidence of late-onset sepsis in very low birth weight (VLBW) infants, although this was mitigated in infants with concomitant administration of bovine lactoferrin [39].

Necrotizing Enterocolitis. A prospective, randomized controlled trial of 34 infants published in 1990 found that acidification of infant feeds resulted in a reduced incidence of NEC [43]. This inspired a case-control study published in 2006 involving more than 11,000 ELBW infants to see whether increasing the gastric $\mathrm{pH}$ using an H2RA might conversely increase that risk. It revealed a statistically significant increased incidence of NEC in infants with antecedent HR2A use [44]. A follow-up prospective study published in 2012 demonstrated the use of ranitidine to be associated with an increased risk of late-onset sepsis, NEC, and death in VLBW infants [35]. Furthermore, a retrospective cohort study of more than 120,000 VLBW infants in 348 NICUs across the United States supported this conclusion, with the interesting finding of increased risk of the combined outcome of death, NEC, or sepsis on days in which an infant was exposed to an H2RA, with an odds ratio of 1.14 (95\% confidence interval 1.08-1.19) [36].

Skeletal Fractures. The use of gastric acid-reducing medications is associated with an increased risk of fractures, with multiple proposed mechanisms behind this association. Reduced gastric acidity results in decreased enteral calcium absorption secondary to diminished calcium ionization and reduction of the electrochemical gradient through cellular calcium channels [45], with hypocalcemia and hyperparathyroidism thought to increase fracture risk. Another theory relates to disruption of cells that modify bone health: in vitro human osteoclast studies have shown PPIs to affect osteoclast function and survival, which could adversely affect bone turnover [46]. Regardless of the mechanism, long-term PPI use in adults has been shown to increase the risk of hip fractures and other osteoporosis-related fractures $[47,48]$. Moreover, a study of more than 800,000 infants born in the Military Health System between 2001 and 2013 revealed an increased risk of fracture in 
infants prescribed PPIs alone or PPIs in combination with H2RAs, but not H2RAs alone. The risk was greater the earlier the medications were prescribed and the longer the therapy was continued [37].

Allergic Disease. In the same Military Health System study, the use of acid suppressive medication within the first six months of life was positively correlated to later development of allergic disease, including food allergy (especially cow's milk allergy), allergic rhinitis, contact dermatitis, and eczema. The risk increased with duration of therapy beyond 60 days. This association is proposed to result from alteration of the gastrointestinal tract microbiome and changes in immunoglobulin responses, with an increase in IgE production [38].

Miscellaneous. Gastric-acid suppressive agents have also been reported to have other adverse consequences including chronic kidney disease [49], electrocardiographic QT interval prolongation [40], and in premature infants, severe IVH (grades III and IV) and death [33]. Furthermore, in April of 2020, the U.S. Food and Drug Administration removed the H2RA, ranitidine, from the market because of concerns regarding an impurity within the product, N-Nitrosodimethylamine (NDMA), which may have carcinogenic properties [50].

Drug Interactions. Cimetidine is the H2RA with the greatest number of drug-drug interactions because of its inhibition of Cytochrome P450 enzymes. Pharmaceuticals metabolized by Cytochrome P450 will have increased serum concentrations if administered while an infant is also receiving cimetidine. Famotidine and ranitidine have little or no effect on the Cytochrome P450 metabolism. However, all H2RAs can interfere with calcium and vitamin absorption. Similarly, PPIs can decrease multivitamin and mineral absorption, especially iron. One study reported an increased risk of acquired long QT syndrome with the combined therapy of ceftriaxone and lansoprazole [40]. In addition, there may be unknown drug-nutrient interactions.

Evidence, Equipoise or Error? Despite concerns regarding safety and lack of efficacy, acidblocking agents are used frequently in NICUs worldwide. In a retrospective analysis of their use in 43 NICUs and 122,002 infants in the United States from 2006-2013, nearly one quarter (23.8\%) of infants received either an $\mathrm{H} 2 \mathrm{RA}$ or $\mathrm{PPI}$, and $5.8 \%$ received both during their NICU stay [51]. In a study of care practices reported by survey in England and Wales between 2000 and 2001, 100\% of infants diagnosed with GERD received a trial of H2RAs, and 65\% received a PPI [52]. Citing the safety and efficacy data, the "Choosing Wisely" campaign, which aims to reduce the use of tests and treatments that contribute to "healthcare waste," encouraged neonatal care providers to "avoid routine use of anti-reflux medications for treatment of symptomatic GERD or for treatment of apnea and desaturation in preterm infants." [53]. To this end, Children's Hospital in Boston implemented a quality improvement guideline to reduce the use of acid-suppressing medications. By educating care providers and staff regarding appropriate evidence-based use of these medications, their use was reduced, although there was no concomitant decrease in potentially associated adverse events such as infection, fractures, or NEC. However, the authors reported NEC and fractures to be such rare events in their unit that a conclusion relating to these adverse outcomes with H2RA/PPI use could not be drawn [54]. 


\subsubsection{Promotility Agents: Erythromycin and Metoclopramide}

Promotility agents increase the transit of gastric contents through the $\mathrm{Gl}$ tract, theoretically reducing the volume of nutrients in the stomach and therefore, decreasing the substrate available to reflux. However, studies have not shown consistent improvement in reflux following administration of a promotility agent [2], likely from the lack of a definitive link between gastric emptying time and esophageal reflux [55].

Erythromycin. Erythromycin is a macrolide antibiotic re-purposed in the setting of reflux for its side effect of stimulating GI motility. It does this as a motilin receptor agonist [5]. Similar to the hormone motilin, which is produced by duodenal and jejunal enterochromaffin cells, erythromycin binds to the G-protein-coupled motilin receptor, which stimulates contraction of smooth muscle throughout the entire $\mathrm{Gl}$ tract $[13,56]$. Multiple studies have shown its use to benefit infants with dysmotility, resulting in more rapid attainment of full enteral feeds $[57,58]$. However, in a randomized controlled trial of low-dose erythromycin published in 2003, reflux improved in both treated and control groups during the observed time period, as evidenced by lower esophageal $\mathrm{pH}$. The authors concluded that this resulted from physiologic maturation, rather than as a consequence of treatment [57].

Erythromycin use in infants before two weeks of life has been shown to increase the risk of developing pyloric stenosis [59], though this has been reported most often in doses intended for antibiosis, rather than the lower doses typically used for reflux (up to $12.5 \mathrm{mg} / \mathrm{kg} /$ dose q 6 hours vs $\leq 5 \mathrm{mg} / \mathrm{kg} /$ dose q 6 hours, respectively). Additionally, a rare side effect of macrolide antibiotic use is prolongation of the QTc interval.

\section{Drug Interactions}

Erythromycin is metabolized by the Cytochrome P450 3A (CYP3A) pathway, so serum concentrations of other drugs metabolized by this pathway could be altered with concomitant administration, including sildenafil, some benzodiazepines, theophylline, and digoxin [56]. It has also been reported to increase the risk of arrhythmias and may enhance the QTc-prolongation effect of cisapride (although cisapride has been removed from the market in the United States because of its arrhythmogenic properties).

Metoclopramide. Metoclopramide is a dopamine antagonist used in adults for nausea and gastroparesis and utilized in the setting of GERD for promotion of GI motility by acetylcholineenhanced upper GI tract activity and accelerated gastric emptying with increased LES tone [60]. A systematic review of metoclopramide use in neonates discussed multiple studies that reported improved gastric emptying time or decreased time with a lower esophageal $\mathrm{pH}<4$, but no consistent improvement in reflux-attributed signs was demonstrated. Furthermore, several significant side effects were reported, including dystonic reactions, abnormal eye movements, irritability, drowsiness, emesis, and apnea, likely a result of the ability of metoclopramide to cross the bloodbrain barrier [61]. Moreover, tardive dyskinesia, which involves abnormal, involuntary movements of the lower face, is a known potential side effect of metoclopramide, with its likelihood of development related to the total administered dose and duration of therapy. This adverse effect is particularly worrisome, as it does not necessarily resolve following discontinuation of the medication.

\section{Drug Interactions}


Metoclopramide has few significant interactions with drugs commonly used in the NICU, but its use alone has the potential for significant adverse consequences, as noted previously. Given its mechanism of action, its increase in GI motility is antagonized by anticholinergic drugs and narcotic analgesics. Furthermore, the alteration in GI motility caused by its use can alter the absorption of enteral medications, potentially diminishing those absorbed in the stomach (e.g., digoxin) [62] and increasing those absorbed in the small intestine (e.g., acetaminophen) [60,63].

Pharmacologic agents used to treat GERD are summarized in Table 1.

Table 1 Potential Pharmacologic Agents used for the treatment of GERD in infant.

\begin{tabular}{|c|c|c|c|}
\hline $\begin{array}{l}\text { Pharmacologic } \\
\text { Agent Class }\end{array}$ & Mechanism of Action & $\begin{array}{l}\text { Adverse } \\
\text { Effects/Safety } \\
\text { Concerns }\end{array}$ & $\begin{array}{l}\text { Potential Drug } \\
\text { Interactions }\end{array}$ \\
\hline $\begin{array}{l}\text { Acid Blocker: } \\
\text { Histamine } 2 \\
\text { Receptor } \\
\text { Antagonists } \\
\text { (E.g., ranitidine, } \\
\text { famotidine) }\end{array}$ & $\begin{array}{l}\text { Competitive inhibitor } \\
\text { of histamine at } \mathrm{H} 2- \\
\text { receptors of the } \\
\text { gastric parietal cells; } \\
\text { results in downstream } \\
\text { inhibition of gastric } \\
\text { acid secretion. }\end{array}$ & $\begin{array}{l}\text { Increased risk of } \\
\text { infection, allergic } \\
\text { disease, necrotizing } \\
\text { enterocolitis (NEC), } \\
\text { intraventricular } \\
\text { hemorrhage (IVH), } \\
\text { death }\end{array}$ & $\begin{array}{l}\text { Reduces enteral vitamin } \\
\text { and mineral absorption; } \\
\text { Cimetidine: Inhibits } \\
\text { Cytochrome P450 } \\
\text { Enzymes, may reduce } \\
\text { metabolism of drugs } \\
\text { similarly metabolized; }\end{array}$ \\
\hline $\begin{array}{l}\text { Acid Blocker: } \\
\text { Proton Pump } \\
\text { Inhibitors } \\
\text { (E.g., omeprazole, } \\
\text { lansoprazole, } \\
\text { esomeprazole) }\end{array}$ & $\begin{array}{l}\text { Suppresses gastric } \\
\text { acid secretion by } \\
\text { directly and } \\
\text { irreversibly inhibiting } \\
\text { the parietal cell } \mathrm{H}+\mathrm{K}+ \\
\text { ATP pump }\end{array}$ & $\begin{array}{l}\text { Increased risk of } \\
\text { infection, fracture, } \\
\text { allergic disease, } \\
\text { cardiac arrhythmia }\end{array}$ & $\begin{array}{l}\text { Reduces enteral vitamin } \\
\text { and mineral absorption; } \\
\text { long QT syndrome with } \\
\text { combination of } \\
\text { ceftriaxone and } \\
\text { lanzoprazole }\end{array}$ \\
\hline $\begin{array}{l}\text { Promotility Agent: } \\
\text { Erythromycin }\end{array}$ & $\begin{array}{l}\text { Binds to motilin } \\
\text { receptors, stimulating } \\
\text { contraction of smooth } \\
\text { muscle throughout } \\
\text { the entire Gl tract }\end{array}$ & $\begin{array}{l}\text { Increased risk of } \\
\text { pyloric stenosis, } \\
\text { cardiac arrhythmia }\end{array}$ & $\begin{array}{l}\text { Metabolized by P450 3A } \\
\text { (CYP3A) pathway; may } \\
\text { reduce metabolism of } \\
\text { drugs similarly } \\
\text { metabolized. Enhances } \\
\text { the QTc-prolonging effect } \\
\text { of cisapride }\end{array}$ \\
\hline $\begin{array}{l}\text { Promotility Agent: } \\
\text { Metoclopramide }\end{array}$ & $\begin{array}{l}\text { Dopamine antagonist; } \\
\text { increases GI motility } \\
\text { by acetylcholine- } \\
\text { enhanced upper GI } \\
\text { tract activity and } \\
\text { accelerated gastric } \\
\text { emptying with } \\
\text { increased LES tone }\end{array}$ & $\begin{array}{l}\text { Dystonic reactions } \\
\text { (notably: tardive } \\
\text { dyskinesia), } \\
\text { abnormal eye } \\
\text { movements, } \\
\text { irritability, } \\
\text { drowsiness, emesis, } \\
\text { apnea }\end{array}$ & $\begin{array}{l}\text { Increased GI motility } \\
\text { antagonized by } \\
\text { anticholinergics and } \\
\text { narcotics. The alteration } \\
\text { in GI motility caused by } \\
\text { metocloprimide use can } \\
\text { alter the absorption of } \\
\text { enteral medications }\end{array}$ \\
\hline
\end{tabular}




\subsection{Non-Pharmacologic Strategies}

Several non-pharmacologic strategies, including changes in diet, post-prandial positioning, and avoidance of exposure to tobacco smoke have shown variable benefits related to GERD, both in the subjective clinical signs and the objective measures of GERD, such as frequency of detection of refluxate in the esophagus or esophageal acidity $[2,5,29,64-66]$.

Multiple studies have shown that cow's milk protein allergy in infants may manifest as vomiting with accompanying GERD signs $[65,67]$. In these cases, elimination of cow's milk protein may result in rapid improvement. In breast fed infants, lactating mothers should remove all dairy products from their diets for at least two weeks [2, 29, 66, 68]. In formula-fed infants, this can be done with transition to extensively hydrolyzed protein formulas (eHPF), in which the "protein" content is provided in the form of amino acids or small peptides. Provision of eHPF has been demonstrated to improve GERD in both term and preterm infants $[65,67]$. Therefore, a two-week trial of semielemental formula or a maternal elimination diet may benefit infants whose GER signs relate to a not previously recognized cow's milk protein allergy $[2,65,66]$.

Thickening of feeds has also been proposed as a conservative measure to improve GERD. A systematic review published in 2017 concluded that thickening may reduce the frequency of regurgitation, with an average of two fewer episodes each day in infants receiving thickened feedings [69]. There are formula preparations with rice starch that thicken upon exposure to gastric acid in the stomach or formula can be thickened with rice cereal. However, breast milk cannot be thickened with rice cereal, as amylase in breast milk breaks down its starch, rendering it no longer thickened. Commercial thickeners using xanthan gum as the thickening agent had previously been used for thickening breast milk, but this increased the risk of developing necrotizing enterocolitis in preterm infants [70], and in 2011 the FDA issued a warning against their use [71]. An association between carob bean gum thickener and NEC has also been reported [72]. Other thickeners that contain locust bean gum are available but are not yet approved for use in preterm infants.

Recommendations for infant positioning as they relate to GER is challenging, as well. Multiple studies have demonstrated reduced reflux for infants in prone or left lateral positions compared to supine $[64,73,74]$. In general, the prone position has been found to reduce reflux compared to "upright" positioning [75], as well, though one study specifically investigating infants with otherwise unexplained chronic respiratory signs were found to have reduced GER as measured by multichannel intraluminal esophageal impedance and $\mathrm{pH}$ monitoring in a car seat at 30 degrees compared to a recumbent position [76]. Despite potential alternative positions that may benefit reflux signs, the risk of Sudden Infant Death Syndrome (SIDS) is significantly increased in any position other than supine. Therefore, the American Academy of Pediatrics in its "Back to Sleep" campaign recommends the supine position for all sleeping infants [77]. However, in an infant with significant reflux, when awake and active, prone positioning may decrease reflux, especially in the postprandial period [2].

A 2008 study counseled parents to institute these non-pharmacologic measures at home and evaluated their efficacy using a 12-item reflux questionnaire before and after the interventions. For two weeks, the families were encouraged to change formula-fed infants to semi-elemental formula and thicken the formula with rice cereal, provide more frequent and smaller-volume feeds, avoid dairy and soy in lactating mothers, reduce postprandial seated and supine positions and eliminate exposure to tobacco smoke. In the 37 infants who completed the study, more than three-quarters 
had improved GER signs [66]. While it is not clear which of these interventions was most significant in the improvement of reflux findings, employing these conservative measures in combination may improve symptomatic reflux in the outpatient setting.

\section{Conclusion}

Infantile gastroesophageal reflux is a normal physiologic process. Pathologic GERD may be associated with several signs in the neonatal population, especially in premature infants. While various pharmacologic and non-pharmacologic treatments have been attempted with only modest benefit, there are significant safety concerns that appear to outweigh treatment benefits. Perhaps the treatment that appears to have the greatest support is a "tincture of time." The natural history of GERD improves over time without intervention as the Gl tract matures in the overwhelming majority of affected babies. Clinicians must carefully weigh the risks, which appear to be substantial, and the benefits, which seem minimal, before initiating treatment.

\section{Author Contributions}

Dr. Stepanovich performed the literature review and prepared the manuscript; Dr. Donn conceived the idea for the paper and edited the manuscript.

\section{Competing Interests}

The authors have declared that no competing interests exist.

\section{Reference}

1. Eichenwald EC. Diagnosis and management of gastroesophageal reflux in preterm infants. Pediatrics. 2018; 142: e20181061.

2. Rosen R, Vandenplas $Y$, Singendonk M, Cabana M, Di Lorenzo C, Gottrand F, et al. Pediatric gastroesophageal reflux clinical practice guidelines: Joint recommendations of the North American Society for Pediatric Gastroenterology, Hepatology, and Nutrition (NASPGHAN) and the European Society for Pediatric Gastroenterology, Hepatology, and Nutrition (ESPGHAN). J Pediatr Gastroenterol Nutr. 2018; 66: 516-554.

3. Omari TI, Miki K, Davidson G, Fraser R, Haslam R, Goldsworthy W, et al. Characterisation of relaxation of the lower oesophageal sphincter in healthy premature infants. Gut. 1997; 40: 370375.

4. Omari TI, Benninga MA, Barnett CP, Haslam RR, Davidson GP, Dent J. Characterization of esophageal body and lower esophageal sphincter motor function in the very premature neonate. J Pediatr. 1999; 135: 517-521.

5. Sanchez JB, Jadcherla SR. Gastroesophageal reflux disease in neonates: Facts and figures. NeoReviews. 2021; 22: e104-e117.

6. Corvaglia L, Zama D, Gualdi S, Ferlini M, Aceti A, Faldella G. Gastro-oesophageal reflux increases the number of apnoeas in very preterm infants. Arch Dis Child Fetal Neonatal Ed. 2009; 94: F188-F192.

7. Burton DM, Pransky SM, Kearns DB, Katz RM, Seid AB. Pediatric airway manifestations of gastroesophageal reflux. Ann Otol Rhinol Laryngol. 1992; 101: 742-749. 
8. Jadcherla SR, Slaughter JL, Stenger MR, Klebanoff M, Kelleher K, Gardner W. Practice variance, prevalence, and economic burden of premature infants diagnosed with GERD. Hosp Pediatr. 2013; 3: 335-341.

9. Bamat NA, Kirpalani $H$, Feudtner $C$, Jensen EA, Laughon MM, Zhang $H$, et al. Medication use in infants with severe bronchopulmonary dysplasia admitted to United States children's hospitals. J Perinatol. 2019; 39: 1291-1299.

10. Costa H, Costa TX, Martins RR, Oliveira AG. Use of off-label and unlicensed medicines in neonatal intensive care. PLoS One. 2018; 13: e0204427.

11. Dingeldein M. Development of the neonatal gastrointestinal tract. In: Fanaroff and Martin's Neonatal-Perinatal medicine. 11th ed. Amsterdam, Netherlands: Elsevier; 2020. p. 1506-1512.

12. Dimmitt RA, Sellers ZM, Sibley E. Gastrointestinal tract development. In: Avery's Diseases of the newborn. 10th ed. Amsterdam, Netherlands: Elsevier; 2018. p. 1032-1038.

13. Costa M, Brookes SJ, Hennig GW. Anatomy and physiology of the enteric nervous system. Gut. 2000; 47: iv15-iv19.

14. Oezcelik A, DeMeester SR. General anatomy of the esophagus. Thorac Surg Clin. 2011; 21: 289297.

15. Mittal RK, Balaban DH. The esophagogastric junction. N Engl J Med. 1997; 336: 924-932.

16. Omari T. Lower esophageal sphincter function in the neonate. NeoReviews. 2006; 7: e13-e18.

17. Davidson G. The role of lower esophageal sphincter function and dysmotility in gastroesophageal reflux in premature infants and in the first year of life. J Pediatr Gastroenterol Nutr. 2003; 37: S17-S22.

18. Omari TI, Barnett CP, Benninga MA, Lontis R, Goodchild L, Haslam RR, et al. Mechanisms of gastro-oesophageal reflux in preterm and term infants with reflux disease. Gut. 2002; 51: 475479.

19. Hibbs AM. Maturation of motor function in the preterm infant and gastroesophageal reflux. In: Gastroenterology and nutrition: Neonatology questions and controversies. 3rd ed. Philadelphia, PA: Elsevier; 2019. p. 1-14.

20. Condino AA, Sondheimer J, Pan Z, Gralla J, Perry D, O'Connor JA. Evaluation of infantile acid and nonacid gastroesophageal reflux using combined $\mathrm{pH}$ monitoring and impedance measurement. J Pediatr Gastroenterol Nutr. 2006; 42: 16-21.

21. Frakaloss G, Burke G, Sanders MR. Impact of gastroesophageal reflux on growth and hospital stay in premature infants. J Pediatr Gastroenterol Nutr. 1998; 26: 146-150.

22. Golski CA, Rome ES, Martin RJ, Frank SH, Worley S, Sun Z, et al. Pediatric specialists' beliefs about gastroesophageal reflux disease in premature infants. Pediatrics. 2010; 125: 96-104.

23. Barrington KJ, Tan K, Rich W. Apnea at discharge and gastro-esophageal reflux in the preterm infant. J Perinatol. 2002; 22: 8-11.

24. Di Fiore JM, Arko M, Whitehouse M, Kimball A, Martin RJ. Apnea is not prolonged by acid gastroesophageal reflux in preterm infants. Pediatrics. 2005; 116: 1059-1063.

25. Fuloria M, Hiatt D, Dillard RG, O'Shea TM. Gastroesophageal reflux in very low birth weight infants: Association with chronic lung disease and outcomes through 1 year of age. J Perinatol. 2000; 20: 235-239.

26. Khalaf MN, Porat R, Brodsky NL, Bhandari V. Clinical correlations in infants in the neonatal intensive care unit with varying severity of gastroesophageal reflux. J Pediatr Gastroenterol Nutr. 2001; 32: 45-49. 
27. Ferlauto JJ, Walker MW, Martin MS. Clinically significant gastroesophageal reflux in the at-risk premature neonate: Relation to cognitive scores, days in the NICU, and total hospital charges. J Perinatol. 1998; 18: 455-459.

28. Famotidine: Drug information. Lexicomp Online Database, Hudson, OH: UpToDate, Inc.; 2021. Accessed 03/25/2021; last updated 03/24/2021. Available from: https://somepomed.org/articulos/contents/mobipreview.htm?31/45/32479.

29. Lightdale JR, Gremse DA. Gastroesophageal reflux: Management guidance for the pediatrician. Pediatrics. 2013; 131: e1684-e1695.

30. Olbe L, Carlsson E, Lindberg P. A proton-pump inhibitor expedition: The case histories of omeprazole and esomeprazole. Nat Rev Drug Discov. 2003; 2: 132-139.

31. Omeprazole: Drug information. Lexicomp Online Database, Hudson, OH: UpToDate, Inc.; 2021 [cited date 2021 March 25]. Available from:

http://somepomed.org/articulos/contents/mobipreview.htm?35/22/36192?source=see link.

32. Omari TI, Haslam RR, Lundborg P, Davidson GP. Effect of omeprazole on acid gastroesophageal reflux and gastric acidity in preterm infants with pathological acid reflux. J Pediatr Gastroenterol Nutr. 2007; 44: 41-44.

33. Cotton RB, Hazinski TA, Morrow JD, Roberts $\amalg$, Zeldin DC, Lindstrom DP, et al. Cimetidine does not prevent lung injury in newborn premature infants. Pediatr Res. 2006; 59: 795-800.

34. Orenstein SR, Hassall E, Furmaga-Jablonska W, Atkinson S, Raanan M. Multicenter, double-blind, randomized, placebo-controlled trial assessing the efficacy and safety of proton pump inhibitor lansoprazole in infants with symptoms of gastroesophageal reflux disease. J Pediatr. 2009; 154: 514-520.e4.

35. Terrin G, Passariello A, De Curtis M, Manguso F, Salvia G, Lega L, et al. Ranitidine is associated with infections, necrotizing enterocolitis, and fatal outcome in newborns. Pediatrics. 2012; 129: e40-e45.

36. Romaine A, Ye D, Ao Z, Fang F, Johnson O, Blake T, et al. Safety of histamine-2 receptor blockers in hospitalized VLBW infants. Early Hum Dev. 2016; 99: 27-30.

37. Malchodi L, Wagner K, Susi A, Gorman G, Hisle-Gorman E. Early acid suppression therapy exposure and fracture in young children. Pediatrics. 2019; 144: e20182625.

38. Mitre E, Susi A, Kropp LE, Schwartz DJ, Gorman GH, Nylund CM. Association between use of acid-suppressive medications and antibiotics during infancy and allergic diseases in early childhood. JAMA Pediatr. 2018; 172: e180315.

39. Manzoni P, García Sánchez R, Meyer M, Stolfi I, Pugni L, Messner H, et al. Exposure to gastric acid inhibitors increases the risk of infection in preterm very low birth weight infants but concomitant administration of lactoferrin counteracts this effect. J Pediatr. 2018; 193: 6267.e61.

40. Lorberbaum T, Sampson KJ, Chang JB, Iyer V, Woosley RL, Kass RS, et al. Coupling data mining and laboratory experiments to discover drug interactions causing QT prolongation. J Am Coll Cardiol. 2016; 68: 1756-1764.

41. Palla MR, Harohalli S, Crawford TN, Desai N. Progression of gastric acid production in preterm neonates: Utilization of in-vitro method. Front Pediatr. 2018; 6: 211.

42. Herzig SJ, Howell MD, Ngo LH, Marcantonio ER. Acid-suppressive medication use and the risk for hospital-acquired pneumonia. JAMA. 2009; 301: 2120-2128. 
43. Carrion V, Egan EA. Prevention of neonatal necrotizing enterocolitis. J Pediatr Gastroenterol Nutr. 1990; 11: 317-323.

44. Guillet R, Stoll BJ, Cotten CM, Gantz M, McDonald S, Poole WK, et al. Association of H2-blocker therapy and higher incidence of necrotizing enterocolitis in very low birth weight infants. Pediatrics. 2006; 117: e137-e142.

45. Bronner F. Intestinal calcium transport: The cellular pathway. Miner Electrolyte Metab. 1990; 16: 94-100.

46. Prause $M$, Seeliger $C$, Unger $M$, Rosado Balmayor $E$, van Griensven $M$, Haug AT. Pantoprazole decreases cell viability and function of human osteoclasts in vitro. Mediators Inflamm. 2015; 2015: 413097.

47. Yang YX, Lewis JD, Epstein S, Metz DC. Long-term proton pump inhibitor therapy and risk of hip fracture. JAMA. 2006; 296: 2947-2953.

48. Targownik LE, Lix LM, Metge CJ, Prior HJ, Leung S, Leslie WD. Use of proton pump inhibitors and risk of osteoporosis-related fractures. Can Med Assoc J. 2008; 179: 319-326.

49. Xie Y, Bowe B, Li T, Xian H, Yan Y, Al-Aly Z. Long-term kidney outcomes among users of proton pump inhibitors without intervening acute kidney injury. Kidney Int. 2017; 91: 1482-1494.

50. Food and Drug Administration. FDA requests removal of all ranitidine products (Zantac) from the market [Internet]. USA: FDA; 2020. Available from: https://www.fda.gov/newsevents/press-announcements/fda-requests-removal-all-ranitidine-products-zantac-market.

51. Slaughter JL, Stenger MR, Reagan PB, Jadcherla SR. Neonatal histamine-2 receptor antagonist and proton pump inhibitor treatment at United States children's hospitals. J Pediatr. 2016; 174: 63-70.e63.

52. Dhillon AS, Ewer AK. Diagnosis and management of gastro-oesophageal reflux in preterm infants in neonatal intensive care units. Acta Paediatr. 2004; 93: 88-93.

53. Ho T, Dukhovny D, Zupancic JA, Goldmann DA, Horbar JD, Pursley DM. Choosing wisely in newborn medicine: Five opportunities to increase value. Pediatrics. 2015; 136: e482-e489.

54. Angelidou A, Bell K, Gupta M, Tropea Leeman K, Hansen A. Implementation of a guideline to decrease use of acid-suppressing medications in the NICU. Pediatrics. 2017; 140: e20171715.

55. Ewer AK, Durbin GM, Morgan ME, Booth IW. Gastric emptying and gastro-oesophageal reflux in preterm infants. Arch Dis Child Fetal Neonatal Ed. 1996; 75: F117-F121.

56. Erythromycin (systemic): Drug information. Lexicomp Online Database, Hudson, OH; 2021 [cited date 2021 March 24]. Available from:

https://online.lexi.com/lco/action/doc/retrieve/docid/patch f/1831759?cesid=5VpL658eq8I

\&searchUrl=\%2Flco\%2Faction\%2Fsearch\%3Fq\%3Derythromycin\%26t\%3Dname\%26va\%3Deryt hromycin.

57. Ng SC, Gomez JM, Rajadurai VS, Saw SM, Quak SH. Establishing enteral feeding in preterm infants with feeding intolerance: A randomized controlled study of low-dose erythromycin. J Pediatr Gastroenterol Nutr. 2003; 37: 554-558.

58. Ng PC. Use of oral erythromycin for the treatment of gastrointestinal dysmotility in preterm infants. Neonatology. 2009; 95: 97-104.

59. Cooper WO, Griffin MR, Arbogast P, Hickson GB, Gautam S, Ray WA. Very early exposure to erythromycin and infantile hypertrophic pyloric stenosis. Arch Pediatr Adolesc Med. 2002; 156: 647-650. 
60. Metoclopramide: Drug information. Lexicomp Online Database, Hudson, OH: UpToDate, Inc.; 2021 [cited date 2021 March 24]. Available from:

https://somepomed.org/articulos/contents/mobipreview.htm?36/47/37631?source=see link.

61. Hibbs AM, Lorch SA. Metoclopramide for the treatment of gastroesophageal reflux disease in infants: A systematic review. Pediatrics. 2006; 118: 746-752.

62. Johnson BF, Bustrack JA, Urbach DR, Hull JH, Marwaha R. Effect of metoclopramide on digoxin absorption from tablets and capsules. Clin Pharmacol Ther. 1984; 36: 724-730.

63. Forrest JA, Clements JA, Prescott LF. Clinical pharmacokinetics of paracetamol. Clin Pharmacokinet. 1982; 7: 93-107.

64. Corvaglia L, Rotatori R, Ferlini M, Aceti A, Ancora G, Faldella G. The effect of body positioning on gastroesophageal reflux in premature infants: Evaluation by combined impedance and $\mathrm{pH}$ monitoring. J Pediatr. 2007; 151: 591-596.e1.

65. Corvaglia L, Mariani E, Aceti A, Galletti S, Faldella G. Extensively hydrolyzed protein formula reduces acid gastro-esophageal reflux in symptomatic preterm infants. Early Hum Dev. 2013; 89: 453-455.

66. Orenstein SR, McGowan JD. Efficacy of conservative therapy as taught in the primary care setting for symptoms suggesting infant gastroesophageal reflux. J Pediatr. 2008; 152: 310314.e1.

67. Garzi A, Messina M, Frati F, Carfagna L, Zagordo L, Belcastro M, et al. An extensively hydrolysed cow's milk formula improves clinical symptoms of gastroesophageal reflux and reduces the gastric emptying time in infants. Allergol Immunopathol. 2002; 30: 36-41.

68. Isolauri E, Tahvanainen A, Peltola T, Arvola T. Breast-feeding of allergic infants. J Pediatr. 1999; 134: 27-32.

69. Kwok TC, Ojha S, Dorling J. Feed thickener for infants up to six months of age with gastrooesophageal reflux. Cochrane Database Syst Rev. 2017; 12: CD003211.

70. Beal J, Silverman B, Bellant J, Young TE, Klontz K. Late onset necrotizing enterocolitis in infants following use of a xanthan gum-containing thickening agent. J Pediatr. 2012; 161: 354-356.

71. Hensley S. FDA warns against food thickener for premature infants [Internet]. Washington DC: National Public Radio; 2011. Available from: https://www.npr.org/sections/healthshots/2011/05/23/136574547/fda-warns-against-food-thickener-for-premature-infants.

72. Clarke $P$, Robinson MJ. Thickening milk feeds may cause necrotising enterocolitis. Arch Dis Child Fetal Neonatal Ed. 2004; 89: F280.

73. Omari TI, Rommel N, Staunton E, Lontis R, Goodchild L, Haslam RR, et al. Paradoxical impact of body positioning on gastroesophageal reflux and gastric emptying in the premature neonate. J Pediatr. 2004; 145: 194-200.

74. Ewer AK, James ME, Tobin JM. Prone and left lateral positioning reduce gastro-oesophageal reflux in preterm infants. Arch Dis Child Fetal Neonatal Ed. 1999; 81: F201-F205.

75. Orenstein SR, Whitington PF, Orenstein DM. The infant seat as treatment for gastroesophageal reflux. N Engl J Med. 1983; 309: 760-763.

76. Jung WJ, Yang HJ, Min TK, Jeon YH, Lee HW, Lee JS, et al. The efficacy of the upright position on gastro-esophageal reflux and reflux-related respiratory symptoms in infants with chronic respiratory symptoms. Allergy Asthma Immunol Res. 2012; 4: 17-23. 
77. AAP Task Force on Sudden Infant Death Syndrome. SIDS and other sleep-related infant deaths: Updated 2016 recommendations for a safe infant sleeping environment. Pediatrics. 2016; 138: e20162938.

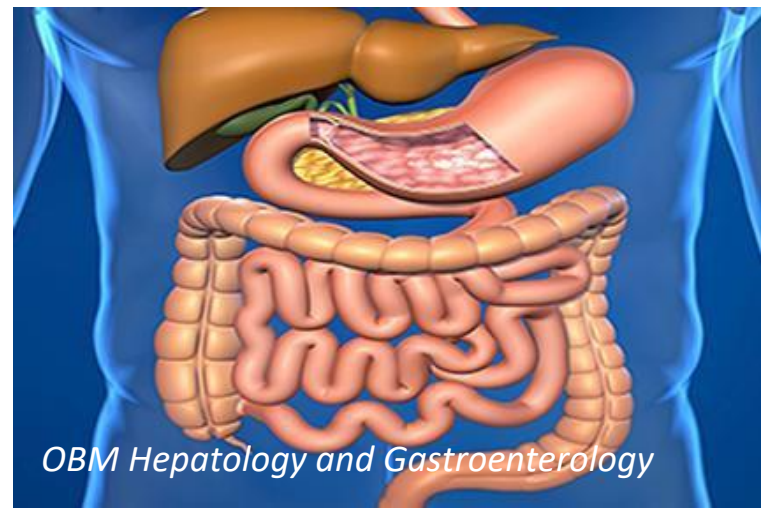

Enjoy OBM Hepatology and Gastroenterology by:

1. Submitting a manuscript

2. Joining in volunteer reviewer bank

3. Joining Editorial Board

4. Guest editing a special issue

For more details, please visit:

http://www.lidsen.com/journals/hg 